\title{
FEEDING FEATURES OF KEFAL FISHES \\ IN NATURAL AREAS
}

\section{Marina Burgaz ${ }^{1}$ \\ Olga Soborova ${ }^{2}$}

DOI: https://doi.org/10.30525/978-9934-588-15-0-130

Abstract. Mullet has always been one of the most important species of commercial fish in the basins of the Black and Azov Seas. The water bodies in which they are grown include the estuaries and lagoons of the northwestern Black Sea. These are highly productive ecosystems that have always been of great fisheries and recreational value. Mullet fish have long been considered one of the most important pasture fish farming objects in the Black, Azov and Mediterranean Sea basins. Representatives of the mullet family have long been valuable objects of pasture fisheries. The mullet family (Mugilidae) belongs to mullet fishes (Mugiliforms), to the thorn group (Acanthopterygii), comprising more than ten genera and ninety-five species. There are five types of mullet in the Black Sea: Mugil cephalus L., Liza aurata (Risso), Lizas saliens (Risso), Chelon labrozus (Risso), Liza ramada (Risso). The first three described species are of industrial importance. For the proper rational organization of the pasture fisheries in the Black Sea estuaries, the information about a state of the food base and the peculiarities of mullet fish feeding, as a major object of mariculture, is essential. The purpose of the study was to investigate the qualitative feeding characteristics of Mugil cephalus L., Liza aurata (Risso), Liza saliens (Risso), and Liza Haematocheilus (Pelengas) in the natural waters of the Azov-Black Sea basin. The studies have shown that mullet larvae choose the fodder organisms by their morpho-physiological features and the properties of the forage objects. The availability of the fodder organisms and the electivity (the larvae preference for one or another forage) were determined. When

\footnotetext{
${ }^{1}$ Candidate of Biological Sciences,

Associate Professor of Aquatic Bioresources and Aquaculture Department,

Odessa State Environmental University, Ukraine

${ }^{2}$ Candidate of Geographical Sciences,

Assistant of Aquatic Bioresources and Aquaculture Department,

Odessa State Environmental University, Ukraine

(C) Marina Burgaz, Olga Soborova
} 
switching to external feeding, the availability of a feed organism for the larvae is determined by its size. The smallest forage organisms are necessary for the Mugil cephalus larvae (50 microns). Forage organisms of 60 microns in size are available for Liza aurata larvae and forage organisms of more than 70 microns are available for Mugil soiuy larvae. The youngest larvae prefer trophophores of mollusks and copepods nauplii. The electivity of rotatoria at all stages of cultivation is negative. Mugil soiuy has the highest nutritional plasticity. The food spectrum of $6-25$ day larvae includes up to 27 food objects. The Black Sea mullet larvae are less plastic. Their ration includes from 20 to 22 food objects. In addition to animal organisms microalgae occupy a prominent place in the diet of even the early larvae of mullet fish. As larvae grow, the concentration of fodder organisms may decrease and their size increases. An increase of the concentration of food organisms does not provide an increase of the ration but only leads to an irrational food consumption, so it makes no sense.

\section{Introduction}

Ukraine has a large enough coastline along the Black and Azov Seas with adjacent vast shelf zones and highly productive soloed inland water bodies occupying several hundreds of thousands of hectares and are located in a friendly natural zone, and have a big science and login-technical base for reproduction and commercial cultivation of hydrobionts.

In the northwestern part of the Black Sea within Ukraine there are shallow estuaries and lagoons: Sasyk, Shagany, Alibey, Burnas, Shabolat, Dnestrovsky, Sukhy, Hadzhibeysky, Kuyalnytsky, Dauphinsky, Grigoryevsky and Tiligulsky. Their total area is more than 1200 square kilometers.

The estuaries and lagoons of the northwestern Black Sea are highly productive ecosystems that have always been of great fisheries and recreational value. These water bodies are under the influence of significant anthropogenic impact. This fact applies to the Black Sea as a whole, but it is the most characteristic for its northwestern part.

The features of natural conditions (the shallowness of the water bodies, desalination, high water temperature, a large number of biogenic elements, etc.), combined with the presence of freshwater, brackishwater and marine forms in the flora and fauna determine a great biological diversity.

More than 200 fish species live in the waters of the Azov-Black Sea 
basin. Mullet has always been one of the most important species of commercial fish in the Black and Azov Sea basin.

A general history of mullet farming dates back to ancient times since the Ottoman Empire. The Burnas, Alibey, Shagany, Sasyk, Shabolatsky, Tiligulsky, Utluksky estuaries, Sivash and others have long been used as feeding ponds for mullet fish.

An abundant forage base of these water bodies and the favorable conditions for fish growing allowed to obtain a significant amount of delicate fish production.

For the proper, rational organization of pasture fisheries in the Black Sea estuaries, the information about the state of the food base and the peculiarities of mullet fish feeding as a major object of mariculture is essential.

\section{Literature review}

Mullet fish has long been considered one of the most important pasture fish farming objects in the Black, Azov and Mediterranean Sea basins. Representatives of the mullet family have long been valuable objects of pasture fisheries. Even in the Roman times mullet fish were used as a mariculture object. They were grown in limans, estuaries, lagoons of the Mediterranean and the Black Seas [1].

The mullet family (Mugilidae) belongs to mullet fishes (Mugiliforms), to the thorn group (Acanthopterygii), comprising more than ten genera and ninety-five species.

Representatives of the mullet family live in the tropical and subtropical seas, as well as in the southern part of the temperate latitudes ranging from $40^{\circ} \mathrm{C}$ north latitude to $40^{\circ} \mathrm{C}$ south latitude. They inhabit coastal seawater, river mouths and lagoons that are connected to the seas. Representatives of this family are characterized by wide plasticity, eugalinality. They are adapted to live over a wide range of temperatures, they are unpretentious to a high oxygen content in the water, which probably accounts for their widespread distribution in the oceans [1].

There are five types of mullet in the Black Sea: Mugil cephalus L., Liza aurata (Risso), Lizas saliens (Risso), Chelon labrozus (Risso), Liza ramada (Risso). The first three described species are of industrial importance.

Chelon labrozus (Risso) and Liza ramada (Risso) are rare, mainly in the western part of the sea and at the Bosphorus. All these species are the Mediter- 
ranean invaders [1]. Mugil cephalus L. live in many water bodies throughout the world. These fish can be found in the tropical, subtropical, and partly in the temperate zones of the Pacific, Indian and Atlantic oceans. In the eastern Atlantic Mugil cephalus L. extends from the Gulf of Biscay to the coast of the western Africa. On the territory of Ukraine Mugil cephalus L . is found almost all over the waters of the Azov and Black Seas. It can also go for feeding into lagoons, estuaries, and gulfs [2]. The habitat of Liza aurata (Risso) is also quite wide. It can be found along the Atlantic coast from the southern shores of Norway and Sweden (and sometimes even of England) and to the south to Morocco and Madeira. This species inhabits the Mediterranean Sea, the Marble Sea and also it has been acclimated in the Caspian Sea. On the territory of Ukraine, like Mugil cephalus L., it is found almost all along the Black Sea and the Azov Sea. It can enter the lakes, estuaries, gulfs and lagoons [3].

Lizas saliens (Risso) is met along the Atlantic coast starting from the Bay of Biscay and ending with the coast of Morocco. It can be met in the Mediterranean Sea (hence the Suez Canal) and the Marble Sea. This species has been acclimated in the Caspian Sea. Within the boundaries of Ukraine it, like others, can be met along all the coast of the Black and Azov Seas. From the coastal shallows it can enter salty and desalinated estuaries, lakes, gulfs. Occasionally it can enter the mouth of the large rivers [2].

In 1972-1973 the far-flung mullet Liza haematocheilus was introduced into the water bodies of the northwestern Black Sea and adapted well to the conditions of the basin due to the mild climate and a rich food base of this basin. Liza haematocheilus has naturalized in the Azov-Black Sea basin and today its quantity exceeds the native Black Sea species [1].

Liza haematocheilus belongs to estuary- maritime type of fish and has the most northerly habitat boundaries among all mullets. Today distributed in the Far Eastern Seas (maternal habitat), in the Azov Sea, the Black Sea and the Mediterranean Sea basins Liza haematocheilus is one of the most valuable commercial fish in Ukraine and occupies a significant place in marine fishing.

\section{Feeding characteristics of mullet fish \\ 3.1. Feeding features of Mugil cephalus $L$.}

A spectrum of the mullet fish ration is quite similar but it is not surprising since the fish belongs to the same family. Mugil cephalus L. is charac- 
terized by a narrow oral cavity. Its lower jaw has a pointed appearance and is somewhat like a scoop. Even more adult Mugil cephalus L. (especially two year old and adult fish) prefer microbenthos, detritus and silt (with a high content of various bacteria) as their main food. When opening the cavity of their stomach, representatives of zoobenthos - multiform worms and crayfish - are also common. In general a mouth and a throat of the mullet are quite well adapted to seizure the food and to strain it.

In his work Andriyashev A.P. considers a pharyngeal apparatus of the mullet as a special functional-morphological type, which has been developing in the course of the evolution of this group as a kind of device for detritus feeding. He described Mugil cephalus L. feeding process as follows: A fish is swimming over the bottom with its head towards the bottom at an angle of 45 degree and with the help of its jaw it is cleansing the layers of detritus with its microbenthic organisms from the bottom using its transverse mouth, which can stick out and has flattened, like knives, jaws. The detritus that enter the oral cavity is filtered through a thick gastric filter and enters the esophagus via the pharyngeal apparatus [4].

Mugil cephalus L., like other mullets, feeds throughout the year (except during the migration and reproduction periods) and it intensifies feeding before the beginning of spring migrations (in March) and especially during the summer grazing and it is the least during the winter.

In a food spectrum of young Mugil cephalus $L$. in the marine area the same objects as in the ration of young Liza aurata (Risso) and Lizas saliens (Risso) are usually found.

According to the scientists for young mullets the predominance of planktonic food is mainly characterized. In particular Zambroborsch F.S. notes that approaching the coast this year Mugil cephalus L. feeds on zooplankton till the deep autumn [5].

In autumn when the amount of plankton decreases, young Mugil cephalus $L$. switches to peritoneal food and the bottom organic film (microbenthos) capturing detritus too. This author also notes that the bottom film consisting of diatom blue-green and brown algae becomes an integral part of this young fish feeding in the second half of the growing season, when a strainer apparatus has already formed [6].

In the Suhoy estuary Mugil cephalus L. fry, unlike Lizas saliens (Risso) fry, feed mainly diatoms (Conscinodiscus, Cocconeis, Navicula, Pleurosig- 
ma, Gyrosima, Nitzschia), with blue-green algae (Oscillatoria, Lyngbya) among them [7]. According to Duka L.A., in the feeding of 1.5-2.5 cm long Mugil cephalus L. fry, which were caught near the Karadag shore, these species of algae are noted.

According to him in the biocenosis of cystosirs the fry of Mugil cephalus $L$., with a total length of about 23-24 mm, mainly feed on planktonic forms of copepods (which are about $98 \%$ in the ration) and bivalve mollusks. So at such sizes they are typical planktonophages. However when they reach a length of about $32 \mathrm{~mm}$, young fish start feeding on detritus and periphyton [8]. The food of this year and one-year mullet including the 2.5-5 cm long Mugil cephalus L. in Suhoy Liman before the beginning of shallow water feeding includes crayfish, worms, mollusks, chironomids, as well as the particles that have settled on the surface of the water. And when young mullet go to the shallow waters they switch to feed on detritus, which is about $90 \%$ of their intestines.

In the work of Bryskina M.M., who studied the peculiarities of Mugil cephalus $L$. feeding in Karkinitsky Bay, was noted that in the ration of these fish there are detritus, mineral particles of the soil, pieces of algae (Cladofora), the remains of planktonic animals. Phytoplankton, namely diatomaceous leaflets, is also very common, and the composition of food may vary at different times of the year [9]. There is also a great coincidence of a species composition of algae found in the mullet intestines with the bottom macrophytes in the estuaries of the northwestern part of the Black Sea, and even the quantitative relationship between algae species from the mullet stomachs and at the bottom of the estuaries was the same. All this led to a conclusion that mullet feeds on algae bottom films. The author also points to the fact that the fish with the stomachs overflowing with algae without impurities of detritus and animal food were often met [10].

With age there is an increase in the intensity of nutrition: According to Meshidze D.H., the average fullness indexes for one-year mullet are 163\%; for 5-year fish $-359 \%$. According to the author's estimates, one-year fish during the next year (i.e. up to two years of age) consume 13 times more food than the weight of their body; this ratio decreases with age (five-year fish 4 times, six-year - 3,5 times) [11].

The young Mugil cephalus L. starts to feed at 5-6 o'clock in the morning, the maximum intensity comes at $12-16$ o'clock in the afternoon, and it 
finishes eating at $8-10$ in the evening (there is no food in the stomachs at night). Sometimes adult fish can feed intensely at night. The composition of organic substances in the stomachs of mullet (mainly the soil and detritus) is $7,096(1.2023 .90) \%$ [11].

\subsection{Feeding features of Liza aurata (Risso)}

Searching the food the Liza aurata (Risso) organs of smell and the external taste sensitivity of the lips and the snout, where the taste buds were found in the epidermis, play the main role. Vision organs play a less role in the taste reactions, but are easily start to search and capture the prey, as well as to seek a food area. At the same time, vision is main in the defense reactions. All this applies not only to Liza aurata (Risso), but also to the other two species - Mugil cephalus L. and Lizas saliens (Risso).

According to scientist Zaitsev Yu.P., who studied the nutrition of Liza aurata (Risso) larvae and early fry in the water areas of the eastern and western parts of the Black Sea, nutrition components: Lamellibranchiata larvae, Sagitta and Copepod eggs, Copepoda naupilus, including Anomalocaram, Monstrilla and other, copepod stage Copepoda, including Pontellidae, Copepoda adults (Animolocare, Pontella, Oithoneminuta, O.similis, Monstrilla, Paracalanus, Acartia, Centropages, Harpacticoida), Cladocera (Podon, Evande, Penilia), small Amphipoda and terrestrial insects were the most common. With regard to a quantitative composition, for example, 354 specimens of $O$. Minuta, 13 speciments of Paracalanusparvus, 70 Copepoda eggs and 4 Lamellibranchiata larvae were found in the stomach of larvae weighting 2 $\mathrm{mg}$ and $5.3 \mathrm{~mm}$ long, and in the stomach of $22 \mathrm{~mm}$ long fry 10 adult Pontellamediterranea and 3 Paracalanusparvus were found [12].

Some authors point out that young Liza aurata (Risso) prefer plankton. In particular Zambriborsch F.S. indicates that these calves and perennials feed mainly on zooplankton.

Almost similar feeding character can be presented in the youth from the Tuzla group of estuaries.

In July and August only the microbenthic algae, detritus, silt, and sands are abolished in the stomachs of the large fish. In particular in the second half of summer a composition of Liza aurata (Risso) food in the Shabolat and Tuzla estuaries, according to the extent of meeting in this area, has indexes. 
In addition much less Microcolius wecksii, Phormodium monile, Amphora, Achnantes, Gyrosigma, Coscinodiscus and other were found in the fish stomachs.

According to other authors young Liza aurata (Risso) consume more benthic organisms in the first months of their feeding. Duka L.A. (1973) in his work argues that Liza aurata (Risso) has two feeding periods:

1 ) when young fish migrate to and along the coast searching the feeding places and

2) when young fish feed directly at the feeding grounds.

If we study the first period we can say that planktonic organisms can be considered as a basis among the components of nutrition. Thus during this feeding period the mass accumulations of planktonic organisms (Copepo$d a$, Cyclopoida, Calanoida $-45-48 \%$ of the total amount) are a food base. Surface film organisms also occupy a fairly large place [12].

As the young fish gradually grow and become more in size, the number of planktonic organisms of Copepoda genus gradually decreases in the ration, and Harpacticoida (up to 85\%) and the bottom molluscs larvae (47\%) take the first place. Also young fish start to take in the benthic organisms of the Amphipoda, Carpellidae, Halacarida, Tanaida and others genus in small quantities [13].

Young Liza aurata (Risso) comparing with young Lizas saliens (Risso) has slightly less pronounced food plasticity. Liza aurata (Risso) begins to move to planktonic-benthic lifestyles earlier, and individuals of this species having reached a length of about $16 \mathrm{~mm}$ already begin to feed on necto-benthic forms and having reached a size greater than $20 \mathrm{~mm}$ begin to consume typical benthic forms of tanaid and settled mollusk larvae [14]. Young fish living in the thicket biocenoses usually feed on planktonic and benthic life forms: Calanoida, Cyclopoida, Harpacticoida, plankton and settled mollusk larvae. In general in the biocenosis of cystosirs young fish begin to eat up to 19 different forms of animal plankton among which the different species of naupilus (Copepoda, Cladocera), Lamellicoida planktonic larvae, the larvae of different insects and other species can be distinguished [10]. There is also a rather large plasticity in the ration of young Liza aurata (Risso), which is shown by the fact that in the different parts of the sea different organisms form a food basis for the fish that are fairly close in size. 
The quantitative and qualitative composition of Liza aurata (Risso) food depends largely on a combination of several factors such as a size of the fish, a season of the year and a type of the water body in which these fish graze. According to Dovgiy N.V. a food spectrum of Liza aurata (Risso) during its graziery varies slightly depending on a season of the year, a size of the fish and a type of the water body in which the fish graze [15].

It was noted that fish with a length of $3 \mathrm{~cm}$ and a weight of $0.3 \mathrm{~g}$ (by weight, $\%)$ :

- in April have: naupilus Copepoda - 0,5, Acartia- 1,0, Harpacticoida2,0, Gammarus - 72,0, detritus - 11,5, Algae - 12,0;

- in May, at a length of $4.5 \mathrm{~cm}$ and weight of $1.0 \mathrm{~g}$ : detritus - 9,0, Algae10,0, Nematodes- close 0,01, Nereis - 1,0, naupilus Copepoda - 0,008, Acartica-1,0, Harpacticoida-1,0, Gammarus - 77,9, Corophium-0,012;

-in June (5.7 cm and weight $1.99 \mathrm{~g}$ ): detritus - 4,4, Algae- 10,0, Nematodes - 0,01, Nereis - 2,70, Nephthys - 0,01, Gastropoda larvae- 0,011, Lamellibranchiata larvae - 0,02, naupilus Copepoda-0,001, Acartia-0,04, Harpacticoida - 0,012, Gammarus - 83,4, and young adults of large sizes (7.8 cm and weight $5.01 \mathrm{~g})$ : detritus - 12,5, Algae - 58,0, Foraminifera 0,01, Nereis - 6,10, Nephthys - 1,0, Gammarus - 22,2, Chironomus - 0,19;

- in July (9.8 cm and $9 \mathrm{~g})$ : detritus 16,9, Algae - 65,8, Foramenifera 0,01, Nereis - 6,8, Hydrobia - 0,05, naupilius Copepoda-0,01, Acartia 0,01, Harpacticoida - 0,06, Sphaeroma - 0,37, Gammarus - 10,0, and larger ones (11 cm and $14.3 \mathrm{~g})$ : detritus - 41,0, Algae - 46,0, Nereis - 2,20, Nephthys - 1,0, Harpacticoida - 0,40, Gammarus - 9,4;

- in August (12.7 cm and weight $22.0 \mathrm{~g}$ ): detritus - 2,81, Algae - 57,0, Nereis - 2,0, larvae Gastropoda - 0,01, Ostracoda - 0,06, Harpacticoida - 0,04, Gammarus - 12,8, and larger (17 cm and weighing $62 \mathrm{~g})$ : detritus 20,0, Algae - 49,0, Foraminifera-0,004, Nereis - 0,99, Ostracoda-0,002, Gammarus - 30,0, Corophium - 0,004;

- in September (22.0 cm and weighing $112 \mathrm{~g})$ : detritus - 15,0, Algae 54,3, Nereis - 2,0, Ostracoda- 1,7, Harpacticoida- 1,0, Gammarus - 26,0;

- in October (23cm and 115g): detritus - 60,0, Algae - 35,9, Gammarus $4,10[15]$.

The study of Liza aurata (Risso) feeding in the East Sivash, where the fish with a length of $2.5-19.0 \mathrm{~cm}$ were analyzed during the entire feeding period (May-November), has led to the conclusion that in this water body 
Liza aurata (Risso) mainly consumes the bottom organic film, which has microphytobenthos, phytoplankton, bacteria, and benthic animals (shellfish and foramonifers). In addition amphipod mollusks, equinoid crayfish, chromonid larvae and polychaetes were found in the Liza aurata (Risso) diet (Zaitsev and Grin, 1960).

Quite often scientists note that Liza aurata (Risso) can feed for quite a long time (about 16-17 hours a day). The fish starts to eat at about six in the morning and finishes at about $10 \mathrm{pm}$. The largest single ration is between 11 and 13 o'clock and is equal to $4-6 \%$ of the body weight. The rate of food digestion differs for different types of consumed food, for example at an average water temperature of $23-24^{\circ} \mathrm{C}$ algae can be digested during $3-4$ hours, and polychaetes and hammarids during 8-9 hours. If the water temperature rises by $2^{\circ} \mathrm{C}$, the rate of food digestion can increase twice from the rate typical for the different food types.

In his work Karpevich A.F. noted that the degree of Liza aurata (Risso) breathing intensity certainly depends on the rate of food digestion. Hungry fish have been shown to consume $0,640 \mathrm{mg}$ of oxygen per $1 \mathrm{~g}$ of the body weight during one hour; after being fed the fish increase the consumption of oxygen to $0.750 \mathrm{mg}$ and reduces to $0.460 \mathrm{mg}$ after 5 hours. Also this scientist believed that the maximum portion of these fish ration is at a later time between 12 and 16 in the afternoon but the Liza aurata (Risso) intense feeding can also be observed at night [15].

In his work studying the seasonal changes in the Liza aurata (Risso) ratio Long N.V. noted that the increase in the level of feed intake runs approximately in parallel with the increase in the water temperature from April to October, with a maximum in June and July. In particular the daily rations of these fish in May are 5-6\%, in June $7-8 \%$, in July $10-11 \%$, in August $10-11 \%$, in September $8-9 \%$, and in early October $3-4 \%$ from the body weight. According to the calculations of the same author Liza aurata (Risso), that entered the estuary for grazing with a body weight of $0.2-0.4 \mathrm{~g}$ and grew an average to $100 \mathrm{~g}$, consumes about $500-700 \mathrm{~g}$ of animal and vegetable food, that is, in average you need somewhere around $5-7 \mathrm{~kg}$ of feed for $1 \mathrm{~kg}$ of fish gain. Under favorable conditions, in particular in quiet and warm weather, young and adult fish do not stop feeding even during the cold season. At this time feeding can be very intensive [14]. 


\subsection{Feeding features of Lizas saliens (Risso)}

In the ration of young Lizas saliens (Risso), while traveling near the coast, the qualitative composition of the food includes the larvae of Lamellibranchiata, Cladocera (Evandetergestine, E.normandi and other species), naupilus and copepoid stages of Copepoda (Monstrilla, Anomalocera, E.normandi and other species), adults Copepoda (Oithona, Acarti, Paracalanus, Pseudocalanus and other species).

Zaitsev A.V. in his work gives the following data regarding the amount of the consumed food: in the stomachs of $4.3 \mathrm{mg}$ and $7.7 \mathrm{~mm}$ long larvae 99 pieces of Oithonaminuta, 4 pieces of Evande, 1 piece of Acartia were found, and in the stomachs of the $6 \mathrm{mg}$ and $8.9 \mathrm{~mm}$ long individuals respectively 3 pieces of Paeacalanusparvus, 2 pieces of E. tergestina, 3 pieces of Calanoida were found. Young fish is feeding for most of the whole day (at night, less than $14 \%$ of empty stomachs are found), the highest degree of stomach fullness is observed in the periods from 8 till 10 and from 18 till 22. Feed belongs mainly to the layer of hyponeiston. As they grow, the young fish feed on the larger prey - pontellids, Decapoda larvae and terrestrial insects.

Grazing in the estuaries zooplankton is the main food of the young fish and detritus microbenthic plays a less role. Specifically it is for the Shabolatsky estuary.

In the second half of the growing season, the bottom film, which includes diatomaceous, blue - green and brown algae, is an integral part of the Lizas saliens (Risso) food. Under intensive feeding conditions, all food passes through the entire gastrointestinal tract for approximately 2-3 hours.

Even more mature fish feed on mainly microbenthos, which includes detritus, blue - green and diatomaceous algae, and silt that contains a very large number of bacteria. The qualitative food composition of this year Lizas saliens (Risso) in the Suhoy Estuary is quite varied and consists of subspecies of the class of Vermes, Copepoda, Cyclops, Harpacticoida, Amphopoda, crustacean eggs, diatoms and other.

In the work of Gordina A.D. this species young fish feeding in the thicket biocenoses is considered in great detail. For example, in the biocenosis of cystosirs, 33 forms are noted in the food spectrum of mullet, and with the growth of the fish the qualitative food composition also changes: the about 20-27 mm in length fry prefer planktonic copepods - colanoid and cyclopid (to almost $90 \%$ of the total number of organisms consumed), but in the 
ration of the $30-35 \mathrm{~mm}$ in length fry nectobenthic forms - harpacticoids, as well as typical benthic forms - amphipods, caprellids, tanaids, marine mites and settled mollusks larvae appear in the ration, in addition to planktonic copepods and diatoms, reds, browns and green algae are also found in a large quantity in the $60 \mathrm{~mm}$ in length fry [16].

A size of single serving of Lizas saliens (Risso) varies depending on a size and a weight of the body. In his work Sinyukov V.I. gives the following data regarding to a size of a single serving: for Lizas saliens (Risso) with an average body weight of $23 \mathrm{~g}$ the weight of a food portion is on average $1.5 \mathrm{mg}$, ie, this figure is about $5 \%$ of the total body weight. The daily ration of young Lizas saliens (Risso) with a length of $14-20 \mathrm{~mm}$ and a mass in the range of $15-40 \mathrm{mg}$ (at a temperature of $23.5-25^{\circ} \mathrm{C}$ ) was from 16 to $28 \%$ of the total body weight, and besides the smaller fry (12 to $14 \mathrm{~mm}$ ) weighting 16-19 $\mathrm{mg}$ have the highest daily food consumption. It was also found that an average daily gain was about $6 \%$ and it used $20-35 \%$ of the food consumed per day, and the maximum daily gain was $10 \%$ (respectively $36-60 \%$ ) of the total body weight. The food digestion has continued for 3-3.5 hours, and in the absence of the food the $23 \mathrm{~mm}$ fry weiting $82 \mathrm{mg}$ lost up to $3 \%$ of the body weight in the daytime [17].

When the cold season comes the intensity of Lizas saliens (Risso) feeding is somewhat suppressed but it does not finish completely.

Currently the daily rations of young Lizas saliens (Risso) are calculated depending on the temperature of the water and a size of the fish, which are fed with a food mixture in the cold season. At a water temperature of $5^{\circ} \mathrm{C}$ for the young fish weighing from 0.6 to 3.8 grams the daily ration is from 45 to $400 \mathrm{mg}$ of food per person a day (from 4 to $8 \%$ of the total body weight), at a water temperature of $8^{\circ} \mathrm{C}$ it is $50-180 \mathrm{mg}(5-9 \%)$, and at a water temperature of $12^{\circ} \mathrm{C}$ (spring) it is $83-225 \mathrm{mg}(7-14 \%)$, that is about twice as much as during the cold months [18].

On the basis of the direct observations the ability of young Lizas saliens (Risso) to conduct collective hunting for atherina fry that held in the large flocks, was established. The mullet, that is held in the flock in the form of a crescent moon, captures the floating young atherini, thereby cutting some of them off and quickly catching these fish [2].

According to the feeding charachter adult Lizas saliens (Risso) is not much different from other types of mullets and feeds throughout the year, except perhaps only the breeding season. 


\subsection{Feeding features of Liza Haematocheilus (Pelengas)}

In the Azov-Black Sea basin, besides detritus, polychaetes, chironomils, juvenile shrimp, shellfish and filamentous algae are the basic food for Liza Haemaocheilus.

In his work Chechun T.I. gave the data on Liza Haemaocheilus feeding in the Kerch Strait and in the Sea of Azov [19]. In the Kerch Strait region an average stomach fullness index from May to September ranged from 2.3 to 18.5 . The maximum index was 60.7. During this period seasonal fluctuations were detected in Liza Haemaocheilus feeding [20].

In May 1996 Foramenifera - 89,9\% was the basis of the food lump (at the same time Cirripedia content was only about 7.5\%) and in June of the same year it was Crustacea (including Acartiaclause - 51\%). In MayJune 1996-1997 the occurrence of Copepoda in the stomach of Liza Haemaocheilus fluctuated in the range of 31-78\%, Malacostraca, Gastropoda were maximum at the level of $21 \%$ and $10 \%$ respectively, Bivalvia $-35 \%$, macro- and microalgae $-72 \%$ and 20\% maximum. In June 1997 crayfish were of great importance in Liza Haemaocheilus feeding, the number of Crustacea reached $98.6 \%$ including $89.9 \%$ of Copepoda, $6.9 \%$ of Ostracoda. $77 \%$ of microalgae, $17 \%$ of Ostracoda, 33\% of Bivalvia, Copepoda, Malacostraca were found there. In August 1997 the proportion of microalgae and gill stamens in the food breast and the frequency of their occurrence in the stomachs was $100 \%$ (the number of fish equals 4 specimens) [19].

In June 1997 the author collected a large number of stomachs (90 pieces), that made it possible to give a more detailed description of Liza Haemaocheilus feeding. Like in the other months Liza Haemaocheilus favored Copepoda: $63.6 \%$ of a total number were found in the food breast (Acartiaclause - 80 and Bivalvia - 22.7). An average number of Copepoda and Bivalvia per Liza Haemaocheilus stomach was 275 and 274 with a maximum of 4.8 and 3.0 thousand specimen; Ostracoda, Malacostraca and Gastropoda were 3.8 and 20 times less than Copepoda and Bivalvia, respectively [19].

The frequency of macroalgae occurrence in the stomachs was $71 \%$ out of 89 stomachs, they were found in 60 of them. The frequency of Copepo$d a$ occurrence was $42 \%$ that was twice as much as Malacostraca and four times as much as Ostracoda, Bivalvia and microalgae.

Out of 89 Liza Haemaocheilus stomachs there were fragments of their own gill-stamen epithelium in 20 stomachs. 40, 45 and 15\% of Liza Hae- 
maocheilus had respectively, 50, from 51 to 95 and $100 \%$ of the epithelium of the gill stamens. This phenomenon is probably explained by the fact that when the filter apparatus is clogged (sticking of sludge, mechanical particles, grease, sand, winding algae), the old epithelium begins to flake and collapse. In the stomachs of other Black Sea mullets (Liza aurata (Risso), Lizas saliens (Risso) and Mugil cephalus L.), the particles of the gill stamens epithelium were also found. Most likely for Liza Haemaocheilus as well as for other types of Black Sea mullets, a peculiar renewal of the filter apparatus is characteristic [19].

In the Sea of Azov a stomach fullness index of Liza Haemaocheilus increased from 0.3 to 61.6 from April to July 1997. Wherein, the maximum individual stomach fullness index was 170 [19].

In March there were 6 microalgae species in the stomach of one single Liza Haemaocheilus, most of them (5 species) - Diatomea, belonging to two classes: Centrophyceae and Penatophyceae, and one species - Dinophyceae. The frequency of microalgae occurrence in the stomach of Liza Haemaocheilus was $100 \%$.

In April Foraminifera - 88,2\%, Copepoda та Gastropoda - 5.6\% and $5.4 \%$ respectively were the basis of the food lump. The rate of microalgae occurrence in the stomach of Liza Haemaocheilus was 67\%, Copepoda, Gastropoda and Foraminifera-50\% each, Ostracoda - 33\%, veligers Bivalvia and metatrophoraPolychaeta - 17\% each. In June-July veggie, sedentary and quite infrequent adults of Gastropoda were found in the food breast (53,7\%, out of them Hydrobia - 98,0\%), Ostracoda (39,2\%).

The frequency of occurrence of Ostracoda in Liza Haemaocheilus stomachs was $74 \%$, Gastropoda -65 , Bivalvia $-35 \%$, Copepoda $-26 \%$ and microalgae $-18 \%$.

In July 1997 the ration of Liza Haemaocheilus was consisted of Ostracoda (55.1\%), Gastropoda was about 2 times less (30\%, Hydrobia was $99 \%$ out of them). Bivalvia, in turn, was almost 2 times less than Gastropo$d a-14.3 \%$. The occurrence of Ostracoda and Gastropoda in the stomachs was the same and was $100 \%$, Bivalvia - 75, Copepoda $-25 \%$, and other food components $-12 \%$.

In June - July 1996 and 1997, an average number of ostracods per a stomach was 732, Gastropoda - 558, the maximum was 3.3 and 4.8 thousand specimen, respectively. An average number of Bivalvia and Copep- 
oda per a Liza Haemaocheilus stomach was 3.7 and 12.6 times less than Gastropoda, respectively. In the stomachs of two fish approximately 600 veligers of the new Black and Azov Sea invader - the two-billed mollusk Cuncarcacarnea - have been found [21].

In 1996-1997 a size of the food components of Liza Haemaocheilus in the Kerch Gulf and in the Sea of Azov did not exceed 1100 microns: Copepoda - 150-400, Cladocera - 500-700, Ostracoda - 400-1100, Bivalvia - 80-500 microns.

Among the filter fish a filter apparatus plays a very important role in feeding. Liza Haemaocheilus gill stamens are similar to those found in the plankton-eating fishes such as some herring (Clupeidae), whitefish (Corengonidae), anchovy (Engraulidae) and others. However Liza Haemaocheilus gill stamens are much shorter than the other filter fish have [22].

For example, in the case of $15 \mathrm{~cm}$ long Alosa Kessleripontica herring and $25 \mathrm{~cm}$ long Liza Haemaocheilus the gill stamens are 9 and $3 \mathrm{~mm}$ respectively. The ratio of planktonoid fishes gill petals and stamens is equal to one another. Sometimes a slight increase to one or the other part may be observed. For adult 25 and $60 \mathrm{~cm}$ long Liza Haemaocheilus this ratio is one to three and one to six. Probably relatively small gill stamens do not allow the Liza Haemaocheilus filtration apparatus to detain large organisms $[22 ; 23 ; 24]$.

Thus it can be concluded that the Liza Haemaocheilus food spectrum was consisted of the representatives of six animal types as well as of microand macroalgae.

In the Kerch Strait Liza Haemaocheilus mainly consumes naupilius and adult Copepoda and Bivalvia at various stages of the development. Copepoda, Malacostraca, Bivalvia as well as macro- and microalgae prevailed by frequency of the occurence. In the Azov Sea Ostracoda, Gastropoda prevailed by a number in the food breast and in average per one stomach. Octracoda, Gastropoda, micro- and macroalgae were the most frequent per one stomach.

According to the results the stomach fullness index was different in the Azov Sea and the Kerch Strait at the same period and the food components differed. For Liza Haemaocheilus in the Kerch Strait this index was lower. This may be due to the fact that the intensity of food consumption is reduced for the fish from the strait going to spawn. 
In addition Liza Haemaocheilus bearing move to spawn was observed in the coastal area, where some food shortages for fish are possible. The low Liza Haemaocheilus stomach fullness indexes in the Kerch Strait at the end of spring and in the beginning of summer and in the Azov Sea in early March are most likely due to the deterioration of a food base during these periods of the year. In the Kerch Strait Copepoda and Bivalvia mainly dominated in a food spectrum of Liza Haemaocheilus, and in the Sea of Azov Ostracoda and Gastropoda dominated. Obviously this is due to the fact that these food components were the most widespread and available for Liza Haemaocheilus feeding in these areas [25].

From the microalgae Peridinium, Consinidiscus, Diatomea, Nitzschia, Sceletonema, of macroalgae - Enteromorpha, Cladophora, Ectocarpus, Cystoseira, Polysiphonia, Ceramium were the most often found in the stomachs of Liza Haemaocheilus.

In his work Shekk P.V. [26] provides data on a number of differences in the Mugil cephalus L., Liza Haemaocheilus, Lizas saliens (Risso) and Liza aurata (Risso) feeding in the Shabolat estuary in different periods from August to September during 1992-2002.

\section{Conclusions}

A food spectrum of mullet fish is quite similar but this is not surprising because all represented species belong to the same family.

As for the marine area, a food spectrum is not qualitatively different for all presented species of mullets, there are only quantitative differences.

One year Mugil cephalus L. prefer zooplankton when feeding in the marine area. In autamn when a number of zooplankton gradually decreases young Mugil cephalus L. switches to periphoton feeding and to the bottom organic film capturing detritus at the same time.

In the Suhoy estuary Mugil cephalus L. fry, unlike Lizas saliens (Risso) fry, consumes overwhelmingly diatomaceous algae and blue-green algae which are sometimes found among them. As for this year Mugil cephalus $L$. in the Suhoy estuary the crustaceans, worms, mollusks and chironomids are also included in their food spectrum.

In the biocenosis of cystosir Mugil cephalus L. fry prefer planktonic forms of the copepods, which make up about $98 \%$ of the total food spectrum of the fry. 
Young Liza aurata (Risso) prefer plankton food, namely zooplankton, which is the main nutrient for young fish. But for adults the composition of a food spectrum is different. Algae, detritus, silt and sand occupy the main place instead of zooplankton.

In the Gulf of Carnitine a Liza aurata (Risso) food spectrum includes detritus, mineral soil particles, algae peaces and planktonic plant residues. Phytoplankton and algae bottom films are also included but in much less quantities.

Comparing the composition of a food spectrum of Liza aurata (Risso) and Lizas saliens (Risso) it can be seen that Liza aurata (Risso) food plasticity is much less pronounced. Liza aurata (Risso) begin to migrate to the benthic lifestyle and feed on benthic organisms at an earlier age than Lizas saliens (Risso).

In the eastern Sivash one-year and two-year old Liza aurata (Risso) feed on primarily organic film, which includes microphytobenthos, phytoplankton and bacteria throughout the entire grazing period.

For young Lizas saliens (Risso) zooplankton is a major component of the food and microbenthos and detritus are much less in a food spectrum. One-year and two-year-old fish primarily consume detritus, blue-green and diatoms. Mule that contains a fairly large number of bacteria is also included in their food composition.

Planktonic animals, micro- and macroalgae are the main components of a food spectrum of Liza Haematocheilus in the Kerch Strait and in the Sea of Azov.

In the Kerch Strait Copepoda, sedimenting Bivalvia, as well as microand macroalgae are the main constituent of a food spectrum of Liza Haematocheilus. In the Azov Sea Liza Haematocheilus mainly feeds on different stages of Copepoda, young and adult Ostracoda, mollusk larvae, microand macroalgae, sedentary forms of Gastropoda. This difference in Liza Haematocheilus feeding is explained by the fact that in these two areas these food components are main and the most widespread.

Liza Haematocheilus, on the example of the Shabolatsky estuary, consumes primarily detritus and zoobenthos. During the summer a food spectrum also includes residues of aquatic plants and periphyton.

\section{References:}

1. Shekk P.V., Kulikova N.I. (2005). Marikultura ryb i perspektivy ee razvitiya $v$ Chernomorskom bassejne: Monografiya [Mariculture of fishes and prospects for its development in the Black Sea basin: Monograph]. Kyiv: KNT, 308 p. 
2. Movchan Yu.V. (2011). Ryby Ukrainy [Fish of Ukraine]. Kyiv: Zoloti Vorota, 420 p. (in Ukrainian)

3. Andriyashev A.P. (1954). Ryby morej SSSR [Fish of the seas of the USSR]. [opredeliteli po faune. 53]. M.-L.

4. Andriyashev A.P. (1954). O sposobah pitaniya ryb planktonom [About the ways of feeding fish with plankton]. Priroda, vol. 4, pp. 79-81.

5. Zambriborsh F.S. (1962a). Biologiya zimovki kefali [The biology of mullet wintering]. Vopr. Ihtilogii, vol. 4, no. 2, pp. 615-625.

6. URL: www.booksshare.net/index.php?id1=4\&category=biol\&-ls\&book= 1976\&page $=60$

7. Petrov G.P. (1951). Izmenenie sposobov vedeniya kefalnogo hozyajstva $v$ Izmailskoj oblasti [Changing the ways of mullet farming keeping in the Izmail region]. Rybnoe hoz-vo, M., vol. 5, pp. 35-37.

8. Duka L.A. (1973a). Pitanie i pishevye vzaimootnosheniya lichinok i molodi ryb nekotoryh ekologicheskih gruppirovok i biocenoze cistoziry: Soobsh. 1. [Feeding and feeding relationships of larvae and fish juveniles of some ecological groups and biocenoses of cystosir: Society 1]. Kiev: Biologiya morya, vol. 31, pp. 46-70.

9. Bryskina M.M. (1954). Tipy pitaniya promyslovyh ryb Chernogo morya (stavridy, skumbrii, barabuli, chernomorskoj pikshi, kefali) [Types of food of the Black Sea commercial fish (scad, mackerel, porpoise, Black Sea haddock, mullet)] Tr. VNIRO. vol. 28, pp. 136-150.

10. Duka L.A., Gordina A.D. (1971). Vidovoj sostav i pitanie molodi ryb Chernogo morya $v$ zaroslyah cistoziry [Species composition and young Black Sea fish feeding in the cystosyre thickets]. Kiev: Biologiya morej, vol. 23, pp. 133-159.

11. Meshidze D.K. (1960). Biologiya lobana okolo beregov Gruzii [Biology of the loban near the coasts of Georgia]. Batumi: Gosizdat, p. 83.

12. Zajcev Yu.P. (1960). Osobennosti razmnozheniya kefalej (Mugilidae) Chernogo moray [Features of the Black Sea mullet (Mugilidae) breeding.]. Zoologicheskij zhurnal, vol. 10, no. 39, pp. 1538-1544.

13. Starushenko L.I., Bushuev S.G. (2001). Prichernomorskie limany Odessy $i$ ih rybohozyajstvennoe ispolzovanie [Odessa Black Sea estuaries and their fishery use]. Odesa: Astroprint, vol. 151, p. 10.

14. Dolgij V.N. (1968). Biologiya singilyaMugilauratusRisso $v$ usloviyah morskih limanov Dunajsko-Dnestrovskogo mezhdurechya [Biology of Mugilauratus Risso in the conditions of the Danube-Dnestrovsky rivers]. Kishinev: Uchen. Zap. Un-ta., no. 89, pp. 93-104.

15. Karpevich A.F. (1958). Potreblenie kisloroda morskimi rybami pri ih raznom fiziologicheskom sostoyanii [Oxygen consumption by marine fishes at their different physiological state]. Vopr. Ihtiologii.

16. URL: http://vuzlib.com.ua/articles/book/8668-Uslovija_formirovanija_ kormovo/2.html

17. Vinogradov K.O. (1960). Ihtiofauna severo-zapadnoj chasti Chernogo moray [Ichthyofauna of the northwestern part of the Black Sea]. Kyiv: AN URSR, p. 116.

18. Shekk P.V. (1983). Ob energeticheskom obmene i pishevyh racionah ostronosa $v$ usloviyah zimovki. Fiziologicheskie osnovy vosproizvedeniya morskih 
i prohodnyh ryb [On energy metabolism and food rations of the islander in winter conditions. Physiological bases of reproduction of marine and passage fish]. Moscow: Leg. Prom-st, pp. 81-85.

19. Chechun T.Ya. (2002). Pitanie pilengasa $v$ Kerchenskom prolive i Azovskom more [Pilengas feeding in the Kerch Strait and the Azov Sea] gidrobiologicheskij zhurnal. T. 38, vol. 3, pp. 45-51.

20. Shekk P.V. Burgaz M.I. (2017). Harakteristika Pitaniya Kefalevyh Rybv Shabolatskom Limane [Characteristics of Cephalis Fishes Feeding in the Shabolat Liman]. Scientific Journal «ScienceRise:Biological Science», vol. 4(7), pp. 21-26.

21. Chihachev A.S., Frolenko L.N., Grekov Yu.I. Dvustvorchatyj mollyusk Anadara-vselenec v Azovskoe more [The bivalve mollusc Anadara is an invader of the Sea of Azov]. Osnovnye problemy rybnogo hozyajstva i ohrana hozyajstvennyh vodoemov Azovskogo bassejna: Sb. nauch. tr. AzNIIRH, pp. 165-168.

22. Shekk P.V. Burgaz M.I. (2018). Ekologo-biologichna harakteristika kefali pilengasa Lizahaematocheilus (TemmincketSchlegel, 1845) v limanah pivnichno-zahidnogo Prichornomor'ya [Ecological and biological characteristics of Lizahaematocheilus mullet (TemmincketSchlegel, 1845) in the estuaries of the northwestern Black Sea] Proceedings of the Suchasni problemi teoretichnoyi $i$ praktichnoyi ihtiologiyi: XI mizhnarodna ihtiologichna naukovo-praktichna konferenciya (Ukraine, Lviv, September 18-20, 2018), pp. 179-183.

23. Burgaz M.I. (2018). Osoblivosti harchuvannya kefalevih rib v prirodnih akvatoriyah [Mullet fish feeding in natural waters]. Proceedings of the Ekologichni problemi navkolishnogo seredovisha ta racionalnogo prirodokoristuvannya $v$ konteksti stalogo rozvitku (Ukraine, Herson, October 25-26, 2018), Herson, pp. 366-370.

24. Shekk P.V. Burgaz M.I. (2017). Osobennosti pitaniya i pishevye vzaimootnosheniya kefalevihryb v Shabolatskom limane, kak faktor opredelyayushij strategiyu ih pastbishnogo vyrashivaniya [Feeding characteristics and feeding relationships of mullet in the Shabolat estuary as a factor determining the strategy of their grazing]. Proceedings of the Suchasni problemi teoretichnoyi i praktichnoyi ihtiologiyi: Materiali X mizhnarodnoyi ihtiologichnoyi naukovo-praktichnoyi konferenciyi (Ukraine, Kyiv, September 19-21, 2017). Kyiv, pp. 382-384.

25. Pryahin Yu.V., Shnickij V.A. (2006). Metody rybohozyajstvennyh issledovanij [Methods of fisheries research]. Krasnodar: Kubanskij gosuniversitet, p. 214.

26. Shekk P.V., Kryukova M.I. (2010). Ocenka kormovoj bazy i perspektiva ispolzovaniya Shabolatskogo limana dlya pastbishnoj marikultury [Estimation of the forage base and the prospect of using the Shabolat estuary for pasture mariculture]. Zaporizhzhya: Visnik zaporizkogo nacionalnogo universitetu, pp. 126-135. 